\title{
A METHODOLOGY FOR EVALUATING FIELD PERFORMANCE AND EMISSIONS OF A GAS MICROTURBINE BASED COGENERATION SYSTEM
}

\author{
A. F. Orlando ${ }^{a}$, \\ M. M. Huamanía, \\ L. DoVal ${ }^{\mathrm{a}}$, \\ and J. V. Araujo \\ ${ }^{\mathrm{a}} \mathrm{PUC}$ - RIO \\ Departamento de Engenharia Mecânica \\ Laboratório de Avaliação Metrológica e \\ Energética - LAME \\ Rua Marquês de São Vicente 225, Gávea \\ CEP. 22453-900, Rio de Janeiro, Brasil \\ marlonmax@puc-rio.br \\ ${ }^{b}$ LIGHT \\ Superintendência de Projetos Especiais - \\ Pesquisa e Desenvolvimento \\ Av Marechal Floriano 168, Centro \\ CEP. 20080-002, Rio de Janeiro, Brasil
}

\section{ABSTRACT}

Due to its high economic impact, when a new technology is handed over from manufacturer to customer, the contractually fixed guarantees and specifications have to be proven. Besides guarantees concerning environmental tasks, such as flue gas emissions, the availability and performance data of the new technology are the key issue. Field performance usually lacks very accurate measuring equipments and stable measurement conditions, as in many manufacturer testing laboratories. In this work a methodology was developed to evaluate performance and emissions under field conditions, together with a critical analysis of the resulting uncertainty of the main parameters, which are representative of the system performance, which was also detailed. In order to overcome field measurement difficulties, a methodology was used to measure combustion air flow rate from emission and gas flow rate measurements. The evaluation procedure was demonstrated by testing a microturbine based cogeneration system, which comprises a microturbine, a heat recovery system, and a steel storage hot water tank, providing electrical energy to Pontifical Catholic University of Rio de Janeiro grid and thermal energy for heating domestic water in cogeneration to its gymnasium showers. Data were acquired at carefully chosen stable test periods in which the gas microturbine was setup to produce electrical energy at nominal power outputs of $100,75,50$ and $25 \%$ of maximum load. In addition, this paper presents an economical analysis for the system, which operates during peak hours (17:30 to 20:30) from Monday to Friday.

Keywords: cogeneration; gas emission; microturbine; performance; uncertainty

\section{NOMENCLATURE}

AFR air to fuel ratio

C concentration of gaseous pollutants, $\mathrm{mg} / \mathrm{m}^{3}$

$\mathrm{C}_{\mathrm{n}} \mathrm{H}_{\mathrm{m}}$ equivalent hydrocarbon composition

$\mathrm{C}_{\mathrm{P}}$ fluid specific heat at constant pressure, $\mathrm{kJ} /(\mathrm{kg} . \mathrm{K})$

f electrical frequency, $\mathrm{Hz}$

$\mathrm{HI}$ fuel input energy, $\mathrm{kW}$

I current, Amp

LHV lower heating value, $\mathrm{kJ} / \mathrm{kg}$

$\mathrm{M}$ molecular mass, $\mathrm{g} / \mathrm{mole}$

$\mathrm{m}$ mass flow rate, $\mathrm{kg} / \mathrm{s}$

$\mathrm{P}_{1}, \mathrm{P}_{2}, \mathrm{P}_{3}, \mathrm{P}_{4}, \mathrm{P}_{5}, \mathrm{P}_{6}, \mathrm{P}_{7}, \mathrm{P}_{8}, \mathrm{P}_{9}$ product coefficients in equation combustion, $\%$

$\mathrm{P}$ pressure, $\mathrm{kPa}$

$\mathrm{P}_{\mathrm{O}} \quad$ power output, $\mathrm{kW}$

ppm parts per million

$\mathrm{Q}$ heat recovery rate, $\mathrm{kW}$

$\mathrm{R}_{1}, \mathrm{R}_{2}, \mathrm{R}_{3}, \mathrm{R}_{4}, \mathrm{R}_{5}$ reactant coefficients in combustion equation, $\%$

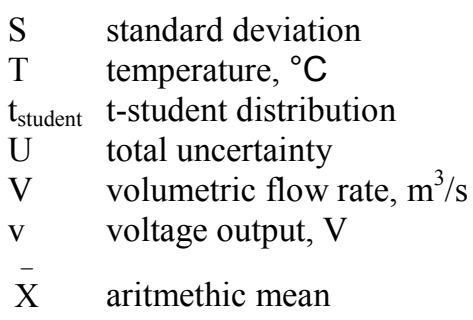

\section{Greek symbols}

$\eta \quad$ efficiency, $\%$

$\rho \quad$ specific mass, $\mathrm{kg} / \mathrm{m}^{3}$

$\mu \quad$ relative uncertainty

$\partial$ partial derivative

\section{Subscripts}

$\begin{array}{ll}\text { AMB } & \text { ambient } \\ \text { EXIN } & \text { exhaust gas inlet } \\ \text { EXOUT } & \text { exhaust gas outlet }\end{array}$ 


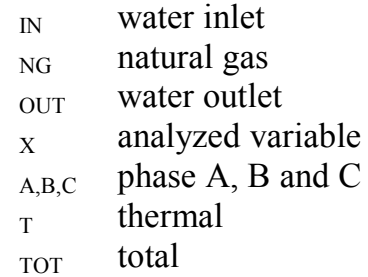

\section{INTRODUCTION}

Nowadays, technological advances have improved the overall economics to the extent that the microturbine can now offer many potential solutions to various utility and waste-heat requirement problems. The actual benefits depend largely on the particular situations, but cost savings and improved reliability/power quality are examples of the types of results that can be expected (Ho et al., 2004).

The present work proposes to show the operation and evaluation of a gas microturbine based cogeneration system, providing electrical energy to Pontifical Catholic University of Rio de Janeiro (PUC-Rio) grid from a gas fired $30 \mathrm{~kW}$ microturbine, and thermal energy for heating domestic water in cogeneration to its gymnasium, through a heat recovery system.

The system includes a Natural Gas (NG) fired 30 $\mathrm{kW}$ microturbine, that provides a fraction of electrical grid supplied power and demand, while operating in the Grid Connect Mode; a heat recovery system, that was ducted to the exhaust of the microturbine to heat domestic water for the showers of the PUC-Rio gymnasium, and a steel storage hot water tank.

For performance evaluation, based on economical analysis, it was determined that the microturbine cogeneration system would have to operate during peak hours (17:30 to 20:30) from Monday to Friday, when the utility tariffs are higher. This work also calculates the uncertainty of the main parameters, which are representative of the system performance.

Finally this work also shows the results of the emission study of microturbine based cogeneration system. The operational data were collected to demonstrate the performance and emission of the technology. The system energy performance was monitored and is reported in this paper.

\section{THE GAS MICROTURBINE}

\section{Overview of microturbine systems}

Microturbines are small combustion gas turbines using operating principles developed from the turbocharger technologies, which are available in large trucks and the turbines that exist in aircraft auxiliary power units (Onovwiona and Ugursal, 2006). A microturbine consists of a compressor, combustor, power turbine and electric generator (Capstone, 2001), that is coupled to a digital power electronic equipment to produce high quality electrical power. However, some manufacturers have developed a regenerated system that pre-heats the air as it passes from the compressor to the combustion chamber and increases the efficiency, such as shown in Fig. 1.

The power production process in microturbines (similar to the industrial gas turbines), involves the pressurization of the intake air by the compressor. The compressed air and the fuel are mixed and ignited in the combustion chamber. The resulting hot combustion gas expands in the power turbine, which drives the compressor and provides power by rotating the turbine shaft.

Microturbines are being introduced into the cogeneration market by manufacturers to meet the electrical and thermal demands of both building and industrial applications. They offer a number of advantages when compared to reciprocating internal combustion or gas turbines based cogeneration systems; they include a compact size, low weight, small number of moving parts, and lower noise features. In addition, microturbine based cogeneration systems have high-grade waste heat, low maintenance requirements (but requires skilled personnel), low vibration, and short delivery time. However, in the lower power ranges, reciprocating internal combustion engines have higher efficiency. Besides the use of NG, other fuels like diesel, landfill gas, ethanol, industrial off-gases, and other bio-based liquids and gases can be used (Onovwiona and Ugursal, 2006).

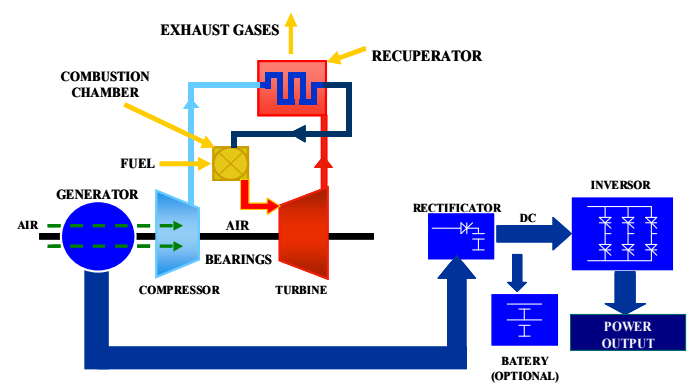

Figure 1. Regenerated microturbine system.

\section{Microturbine emission characteristics}

Microturbines have the potential of producing low emissions. They are designed to achieve low emissions at full load; however, emissions are higher when operating under reduced load. The mains pollutants from the use of microturbines systems are Nitrogen Oxides $\left(\mathrm{NO}_{\mathrm{x}}\right)$, Carbon Monoxide $(\mathrm{CO})$ and Hydrocarbons (total unburnt hydrocarbons - THC), and negligible amount of Sulphur Dioxide $\left(\mathrm{SO}_{2}\right)$. All microturbines operating on gaseous fuels feature a lean premixed (dry low $\mathrm{NO}_{\mathrm{x}}$, or DLN) combustor technology, which was developed relatively recently in the history of gas turbines and is not universally featured on larger gas turbines (EPA, 2002).

Nitrogen Oxides $\left(\mathrm{NO}_{x}\right)$ emissions, form in the gas turbine combustion process as a result of the 
dissociation of Nitrogen $\left(\mathrm{N}_{2}\right)$ and oxygen $\left(\mathrm{O}_{2}\right)$ into $\mathrm{N}$ and $\mathrm{O}$, respectively. Reactions following this dissociation result in seven known oxides of nitrogen: $\mathrm{NO}, \mathrm{NO}_{2}, \mathrm{NO}_{3}, \mathrm{~N}_{2} \mathrm{O}, \mathrm{N}_{2} \mathrm{O}_{3}, \mathrm{~N}_{2} \mathrm{O}_{4}$, and $\mathrm{N}_{2} \mathrm{O}_{5}$. There are three mechanisms by which $\mathrm{NO}_{\mathrm{x}}$ is formed: Thermal $\mathrm{NO}_{\mathrm{x}}$, Prompt $\mathrm{NO}_{\mathrm{x}}$, and Fuel-bound $\mathrm{NO}_{\mathrm{x}}$.

The main $\mathrm{NO}_{\mathrm{x}}$ formation mechanism associated with microturbines is the thermal $\mathrm{NO}_{\mathrm{x}}$ (Onovwiona and Ugursal, 2006), which involves a series of chemical reactions in which oxygen and nitrogen in the combustion air dissociate and subsequently react to form oxides of nitrogen. The formation rate is primarily a function of temperature flame and the residence time of nitrogen at that temperature; this temperature depends on the Air to Fuel Ratio and the air temperature into the combustion chamber (Kehlhofer et al., 1999).

Prompt $\mathrm{NO}_{\mathrm{x}}$ is the formation mechanism of reacting molecular nitrogen in combustion air with hydrocarbon radicals, such as $\mathrm{C}, \mathrm{CH}$, and $\mathrm{CH}_{2}$, and occurring in the earliest stage of combustion.

Fuel-bound $\mathrm{NO}_{\mathrm{x}}$ (also known as organic $\mathrm{NO}_{\mathrm{x}}$ ) are formed when the fuel contains nitrogen as part of the hydrocarbon structure (Onovwiona and Ugursal, 2006). Molecular nitrogen, present as $\mathrm{N}_{2}$ in some $\mathrm{NG}$, does not contribute significantly to fuel $\mathrm{NO}_{\mathrm{x}}$ formation (EPA, 1993).

Carbon monoxide (CO) emissions, in microturbines, is a colorless, odorless, and poisonous gas, that is formed as a result of incomplete combustion of fossil fuel. $\mathrm{CO}$ emissions result when there is insufficient residence time at high temperature (Onovwiona and Ugursal, 2006). CO emissions are also heavily dependent on the operating load. For example, a unit operating under low loads will tend to have incomplete combustion, which will increase the formation of CO (EPA, 2002).

Hydrocarbons or total unburnt hydrocarbons (THC) emissions, are an extensive group of chemical compounds that are composed of hydrogen and carbon. THCs, same as CO, also is a product of incomplete combustion. Emission levels of THCs decrease as combustion temperatures increase. THCs are not pollutant criteria. However, some reactive Volatile Organic Compounds (VOC), which is a subset of THCs, contributes to smog (Capstone, 2000). In general, the THCs emissions rate is function of residence time, the emission characteristics of $\mathrm{CO}$ and $\mathrm{THC}$ are the same with reference to the combustion efficiency (De Carvalho and Teixeira, 2003).

\section{SYSTEM DESCRIPTION}

Such as referenced in ASHRAE (2001), Huamaní (2005) and Orlando (1996), cogeneration or Combined Heat and Power (CHP) system is the thermal system that produces both electrical or mechanical energy (power) and useful thermal energy from a single energy stream such as oil, coal, natural or liquefied gas, biomass or solar.

The CHP system presented in this work utilizes a NG-fired Capstone microturbine model C30 (regenerated) LPNG, a CONUAR heat recovery system ITC1 model, and a steel storage hot water tank. The NG-fired regenerated microturbine, was configured to provide a fraction of electrical grid supplied power and demand, while operating in grid dependent mode; this configured form is called Grid Connect Mode (Capstone, 2004). An autotransformer reduced the microturbine generator's 440-volt, threephase output to 220-volt, three-phase, to match PUCRio electrical distribution system. The NG is delivered to the system at $15 \mathrm{psig}(103 \mathrm{kPa})$. The NG-fired microturbine includes a gas booster compressor that degrades the performance of the microturbine by $2 \mathrm{~kW}$ at standard conditions.

In order to recover the waste heat from the exhaust gas generated by the microturbine, a heat recovery system was used. This system is specifically designed for integration with $\mathrm{NG}$-fired microturbine and can heat domestic water up to $85{ }^{\circ} \mathrm{C}$ to be utilized in PUC-Rio gymnasium showers.

The hot water is pumped through the fin tubes of the heat recovery system by an onboard pump, to a 1000 liter steel storage hot water tank located on the top of PUC-Rio gymnasium. In order to control the hot water outlet temperature, the heat recovery system was equipped with an actuator that opens or closes a divertor flap in the heat recovery system. When the divertor flap is open, the exhaust gas passes through the heat exchanger tubes and gives up heat to the extruded aluminum fins from each tube; when the divertor flap is closed, the turbine exhaust is directed out of the unit without passing through the heat exchanger.

For temperature monitoring, Pt $100 \Omega$ class A (Resistance Thermal Detector - RTD) were used, with 316 stainless steel case. The microturbine CHP system was equipped with pressure transducers. A turbine flowmeter was installed to measure the NG flow rate and heat recovery system outlet water. All temperature, pressure and mass flow readings were continuously measured by a calibrated analog to digital-digital to analog (ADDA) data logger, Agilent 34907A. Flue gas analyses were realized using a combustion TESTO gas analyzer model 454-350 $\mathrm{M} / \mathrm{XL}$. Some detailed specifications of the NG-fired recuperated microturbine, heat recovery system and steel storage hot water tank are provided en Table 1. Instrumentation and points used for measuring parameters are shown in the Fig. 2.

Based on utility tariffs and costs of both electricity and NG, Table 2 shows the economical analysis, for the system operating during peak hours (17:30 to 20:30) from Monday to Friday; it shows that the PAYBACK is 4,7 years and the Internal Rate of Return of Investment (TIR) is $17 \%$ a.a, and the 
annual economy is 5322 US\$/year (considering US \$ $1,0=\mathrm{R} \$ 1,90)$.

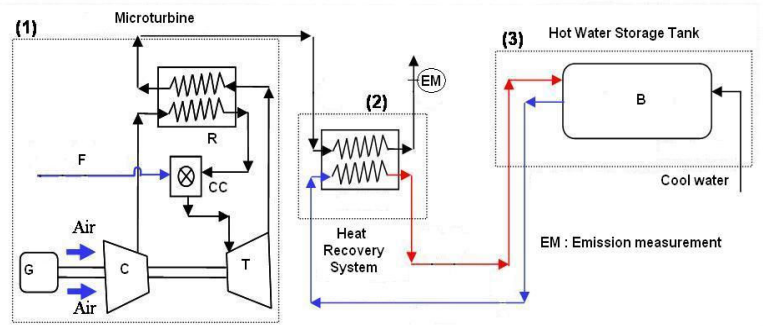

Figure 2. Schematic diagram of the cogeneration system.

Table 1. Specification of NG-fired recuperated microturbine, heat recovery system and steel storage hot water tank.

\begin{tabular}{|l|c|}
\hline \multicolumn{2}{|c|}{ Capstone Microturbine } \\
\hline Nominal Power Output & $30,0 \mathrm{~kW}$ \\
\hline$\eta$ & $25,0 \%$ \\
\hline $\mathrm{HI}$ & $404000 \mathrm{~kJ} / \mathrm{hr}$ \\
\hline $\mathrm{HR}$ & $14400 \mathrm{~kJ} / \mathrm{kWh}$ \\
\hline $\mathrm{T}_{\text {exhaust gas }}$ & $275^{\circ} \mathrm{C}$ \\
\hline $\mathrm{E}_{\text {exhaust gas }}$ & $0,31 \mathrm{~kg} / \mathrm{s}$ \\
\hline $\mathrm{V}_{\text {exhaust gas }}$ Conuar Heat Recovery System \\
\hline \multicolumn{2}{|c|}{$1,5 \mathrm{~kW}$} \\
\hline $\mathrm{P}_{\text {pump }}$ & $3 * 220 \mathrm{~V}-60 \mathrm{~Hz}$ \\
\hline Voltage & $95{ }^{\circ} \mathrm{C}$ \\
\hline $\mathrm{T}_{\text {max H2O }}$ & Water \\
\hline Work Fluid & 1000 liters \\
\hline \multicolumn{2}{|c|}{ Steel Storage Hot Water Tank } \\
\hline Capacity & $220 \mathrm{~V}$ \\
\hline Voltage & Stainless Steel AISI 304 \\
\hline Material & Stainless Steel \\
\hline Tubes & $5 \mathrm{~kW}$ \\
\hline Emergency Power &
\end{tabular}

Table 2. Economical analysis of microturbine CHP system for Peak Hour.

\begin{tabular}{|l|c|c|}
\hline \multicolumn{3}{|c|}{ Economical Analysis of microturbine CHP system } \\
\hline Electric Energy tariff & $\mathrm{US} \$ / \mathrm{kWh}$ & 0,203 \\
\hline Natural Gas tariff & $\mathrm{US} \$ / \mathrm{Nm}^{3}$ & 0,442 \\
\hline Power Output & $\mathrm{kW}$ & 25,0 \\
\hline Efficiency & $\%$ & 22,7 \\
\hline Specific Consumption & $\mathrm{Nm}^{3} / \mathrm{kWh}$ & 0,45 \\
\hline Electric energy supply by MTG & $\mathrm{kWh} /$ month & 1631 \\
\hline Thermal energy of exhaust gas & $\mathrm{kWh} /$ month & 3189 \\
\hline Hot water production $\left(85^{\circ} \mathrm{C}\right)$ & $1 /$ month & 44374 \\
\hline Annual economy & $\mathrm{US} \$ /$ year & 5322 \\
\hline Payback & year & 4,7 \\
\hline TIR & \%a.a. & 17 \\
\hline
\end{tabular}

\section{PERFORMANCE AND EMISSION ANALYSIS}

\section{Performance monitoring}

In this section, a technique for performance analyses and a methodology to calculate the uncertainty of the measurement parameters are presented.

Electrical and thermal performance analysis

Such as referenced in (EPA, 2002) and (EPA, 2003), the specific verification factors associated with the electrical and thermal performance test are:

Heat and Power Production Performance; (i) Electrical power output and heat recovery rate at partial and total load, and (ii) Electrical, thermal, and total system efficiency at partial and total load.

Power Quality Performance; (i) Electrical Frequency, and (ii) Voltage output.

To evaluate power production and energy conversion performance, the Performance Test Code on Gas Turbines (ASME PTC22-1997) has been adopted. Before starting the test, the gas microturbine shall be run until stable conditions have been established, that is achieved when some measured parameters do not vary from the computed average for the operating conditions during the complete run by more than the value shown in Table 3 , that indicates the maximum permissible variations for power output, fuel flow rate, barometric pressure, and ambient air temperature.

The test plan specifies a series of carefully chosen stable test periods in which the system was modulated to produce electricity at selected nominal power output of 28, 21, 14 and $7 \mathrm{~kW}$ (EPA, 2003). Such as gas turbines, gas microturbines have sensitivity to ambient conditions, and because of that, the test run should not exceed 30 minutes, and in no case shall the interval between readings be greater than 10 minutes (ASME PTC-22, 1997). For this work, the duration of the test run was 20 minutes, in which the measurements were taken every 5 minutes, and the hot water temperature was modulated to 85 ${ }^{\circ} \mathrm{C}$.

Table 3. Maximum allowable variation during test periods for some operational parameters (ASME PTC-22, 1997).

\begin{tabular}{|l|c|}
\hline \multicolumn{1}{|c|}{ Measured Parameter } & $\begin{array}{c}\text { Maximum Allowable } \\
\text { Variation }\end{array}$ \\
\hline Power output & $\pm 2 \%$ \\
\hline Fuel flow rate & $\pm 2 \%$ \\
\hline Barometric pressure & $\pm 0,5 \%$ \\
\hline Ambient air temperature & $\pm 2,2{ }^{\circ} \mathrm{C}$ \\
\hline
\end{tabular}

The electrical efficiency of gas microturbine is calculated from Eq. (1)

$$
\eta=\frac{P o}{H I}
$$

To calculate the average fuel mass flow rate; the volumetric flow rate, pressure, and temperature of NG were measured with an in line turbine flow meter, a transducer, and a RTD, respectively. The LHV of NG was supplied by CEG (Local Gas Utility Company of Rio de Janeiro), as an average value of the test day. Then, the fuel input energy was 
calculated using average values from $N$ measurements of the NG mass flow, during the test run, using Eq. (2):

$$
H I=m \cdot L H V
$$

To calculate the average heat recovery rate of water; the volumetric flow rate, and supply and return water temperature were measured with an in line turbine flow meter, and a RTD, respectively, using Eq. (3).

$$
Q_{H 2 O}=V_{H 2 O} \cdot \rho_{H 2 O} \cdot C_{P H 2 O} \cdot\left(T_{O U T}-T_{I N}\right)
$$

The specific mass and specific heat of water were calculated at the supply and return average measured water temperature.

The thermal and total efficiency are calculate using Eq. (4) and Eq. (5):

$$
\begin{gathered}
\eta_{T}=\frac{Q_{H 2 O}}{H I} \\
\eta_{\text {TOTAL }}=\eta+\eta_{T}
\end{gathered}
$$

The power quality is evaluated from electrical frequency and voltage output. When an electrical generator operates in parallel with the utility grid, there are a number of issues of concern; the voltage and frequency from both gas microturbine and grid must be the same. Another parameters that are necessary to indicate are the power factor and transient voltage, but they were not measured in this work.

Electrical frequency and voltage output were measured, and were analyzed to determine the maximum, minimum, average, and standard deviation, respectively.

The average values and the standard deviation from $\mathrm{N}$ measurements of any variables were calculated using Eq. (6) and Eq. (7), respectively.

$$
\begin{gathered}
\bar{X}=\frac{\sum_{i=1}^{i=N} X_{i}}{N} \\
S_{X}=\sqrt{\frac{\sum_{i=1}^{i=N}\left(\bar{X}-X_{i}\right)^{2}}{(N-1)}}
\end{gathered}
$$

\section{Uncertainty analysis}

All measurements of physical quantities are subject to uncertainties. These may be due to bias error in the equipment used for calibration and measurement, or to random scatter caused by, for example, a lack of sensitivity of the equipment used for the measurement (Herschy, 2002).

Uncertainty is a parameter, associated with the result of a measurement (e.g. a calibration or test) that defines the range of the values that could reasonably be attributed to the measured quantity. In this section, a methodology to calculate the uncertainty of the performance parameters, which are representative of the microturbine CHP system, is presented.
The process of estimating uncertainties in the microturbine CHP system is based on certain characteristics of the variables of interest as estimated from its corresponding data set. The information includes: The arithmetic mean (Eq. (6)), The Standard Deviation of the data set (Eq. (7)), and Uncertainty of measurement instrument.

The standard uncertainty is calculated with the Eq. (8):

$$
u_{X}=S_{X}
$$

Such as referenced by Assunção and Orlando (2004), Mendes and Rosario (1995), and ISO GUM (1995), the number of repetitions of a measurement is small, typically varying between three and ten. In these work, we take into account the fact of the sampling is small, for that reason the t-Student distribution $\left(t_{\text {student }}\right)$, value is 3,31 ( 3 degrees of freedom, for 4 measurements), with a confidence level of $95,45 \%$. Considering the uncertainty of measurement instrument, the standard uncertainty is:

$$
u_{C}=t_{\text {student }} * \sqrt{\left(u_{X}\right)^{2}+\left(u_{M}\right)^{2}}
$$

In a general situation the uncertainty value is calculated with the next equation:

$$
U_{C}=\sqrt{\left(\frac{\partial f}{\partial_{a}} U_{a}\right)^{2}+\left(\frac{\partial}{\partial_{b}} U_{b}\right)^{2}+\left(\frac{\partial}{\partial_{c}} U_{c}\right)^{2}+\left(\frac{\partial}{\partial_{d}} U_{d}\right)^{2}+.}
$$

The composition (\%), UHV and LHV $\left(\mathrm{kJ} / \mathrm{Nm}^{3}\right)$, and specific mass of $\mathrm{NG}\left(\mathrm{kg} / \mathrm{Nm}^{3}\right)$, at $20{ }^{\circ} \mathrm{C}$ and $101,325 \mathrm{kPa}$, were obtained from the gas utility company data (CEG), as an average values over the test day, and are shown in Table 4. Such as referenced in Assunção and Orlando (2004), the uncertainty of LHV was estimated in $\pm 1 \%$ through Eq. (11).

$$
u_{L H V}=\sqrt{\left(\left(\sum_{i=1}^{N} L H V_{i} \cdot u_{x_{i}}\right)^{2}+\left(\sum_{i=1}^{N} x_{i} \cdot u_{L H V_{i}}\right)^{2}\right)}
$$

Table 4. Average values of $\mathrm{NG}$ composition for performance and emission at $20^{\circ} \mathrm{C}$ and $101,325 \mathrm{kPa}$.

\begin{tabular}{|l|c|c|c|c|c|}
\hline \multirow{2}{*}{ Com. } & \multicolumn{2}{|c|}{ Perform. monit. } & \multicolumn{3}{|c|}{ Emission performance } \\
\cline { 2 - 6 } & $\begin{array}{c}\text { Stable } \\
\text { test }\end{array}$ & $\begin{array}{c}\text { Long } \\
\text { test }\end{array}$ & Test & $\begin{array}{c}\text { Flue gas } \\
\text { emission }\end{array}$ & $\begin{array}{c}\% \text { or } \\
(\mathrm{ppm})\end{array}$ \\
\hline $\mathrm{CO}_{2}$ & 0,2892 & 0,3060 & 0,004 & $\mathrm{O}_{2}$ & 18,4 \\
\hline $\mathrm{C}_{2} \mathrm{H}_{6}$ & 4,4974 & 4,3911 & 0,496 & $\mathrm{CO}$ & $(1,2)$ \\
\hline $\mathrm{N}_{2}$ & 0,7773 & 0,7355 & 0,022 & $\mathrm{CO}_{2}$ & 1,5 \\
\hline $\mathrm{CH}_{4}$ & 93,5846 & 93,7697 & 0,041 & $\mathrm{NO}$ & $(0,7)$ \\
\hline $\mathrm{C}_{3} \mathrm{H}_{8}$ & 0,7733 & 0,7295 & 0,007 & $\mathrm{NO}_{2}$ & $(0,0)$ \\
\hline $\mathrm{IC}_{4}$ & 0,0223 & 0,0191 & 0,008 & $\mathrm{H}_{2}$ & $(6,3)$ \\
\hline $\mathrm{NC}_{4}$ & 0,0399 & 0,0344 & 0,697 & $\mathrm{HC}$ & $(8,4)$ \\
\hline $\mathrm{IC}_{5}$ & 0,0057 & 0,0049 & 95,123 & -- & -- \\
\hline $\mathrm{NC}_{5}$ & 0,0061 & 0,0053 & 0,298 & -- & -- \\
\hline$>\mathrm{C}_{6}$ & 0,0044 & 0,0044 & 3,304 & -- & -- \\
\hline $\mathrm{UHV}$ & 38475 & 38421 & -- & -- & -- \\
\hline $\mathrm{LHV}$ & 34714 & 34664 & -- & -- & -- \\
\hline$\rho$ & 0,7124 & 0,7111 & 0,7019 & -- & -- \\
\hline
\end{tabular}




\section{Emission monitoring}

The environment has to deal with ever larger concentrations of pollutants due to the use of all types of combustion process. Smog formation, acid rains and the constantly increasing number of allergies are a direct results of this development. The path to environmentally friendly energy production must therefore lead to a reduction in the emission of pollutants, which is only possible when the existing equipment is working correctly and defective equipment is taken off line; for this, flue gas analysis and a flue gas analyzer enable us to measure the concentrations of the pollutants present in a combustion process.

Flue gas analysis includes the detection of gases and vapors in connection with control of chemical and metallurgical process, control of environment and in the field of safety control. A whole class of analytical instruments is available using physical or physical-chemical detecting methods.

Such as referenced above, the flue gas analysis were realized using a combustion TESTO gas analyzer model 454-350 M/XL. This is a self contained emission analyzer system capable of measuring oxygen $\left(\mathrm{O}_{2}\right)$, carbon monoxide $(\mathrm{CO})$, nitrogen oxide $(\mathrm{NO})$, nitrogen dioxide $\left(\mathrm{NO}_{2}\right)$, sulfur dioxide $\left(\mathrm{SO}_{2}\right)$, and hydrocarbons in combustion emission sources, while acquiring data on pressure, temperature, and flow (EPA 2003). Fig. 3 shows a schematic of the model that was used. The uncertainties of the flue gas analysis are: $\mathrm{O}_{2}(2 \%$ of m.v.), $\mathrm{CO}$ (5 ppm), $\mathrm{NO}$ (5 ppm), $\mathrm{CO}_{2}(0.3 \%)$, and $\mathrm{HC}(400 \mathrm{ppm})$.

Such as above, when fuels are burned there remains, besides ash, a certain number of gas components. The presence of pollutants in a flue gas stream can be expressed in terms of the concentrations of the individual gas components, the following units are the most common:

- $\quad$ Parts per million (ppm).

- Milligram per cubic meter $\left(\mathrm{mg} / \mathrm{Nm}^{3}\right.$ or $\mathrm{mg} / \mathrm{m}^{3}$ ).

In the flue gas analysis, for a gas turbine, the data measured are commonly corrected to $15 \%$ oxygen in the exhaust gases, since they operate in an "excess air" mode. Other combustion sources such as IC engines, boilers, furnaces, etc. may be corrected to $3 \%$ to $7 \%$ oxygen, or reported uncorrected (Capstone, 2000).

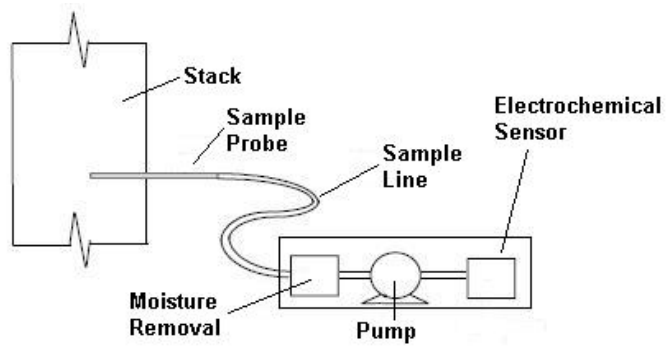

Figure 3. Testo Inc. Model 350 sampling schematic.
Excess air, concentrations of $\mathrm{CO}_{2}$ and $\mathrm{O}_{2}$ were expressed in \%, while concentrations of $\mathrm{NO}_{\mathrm{x}}, \mathrm{CO}$, and $\mathrm{THC}$ were measured in ppm by volume (i.e. volume of gaseous pollutant per million volumes of ambient air) at the test oxygen concentration. Basically, the $\mathrm{SO}_{2}$ concentration found in this research was very low (not exceeding 3 ppmv) and was excluded from further analysis. The levels of $\mathrm{NOx}$ and $\mathrm{CO}$ were corrected to ppmv at $15 \% \mathrm{O}_{2}$ using Eq. (12) and Eq. (13), such as referenced in De Carvalho and Teixeira, 2003.

$$
N O_{x_{-} 15 \%}=\frac{\left(0,21-\left[O_{2}\right]_{\text {corr }}\right)}{\left(0,21-\left[O_{2}\right]_{\text {meas }}\right)} * N O_{x_{-} \text {meas }}
$$

where,

$N O_{x}{ }_{15 \%}$ is the concentration of nitrogen oxides at 15 $\% \mathrm{O}_{2}$ ppmv, [O2] corr is the oxygen corrected value $(15 \%), N O_{x_{-} \text {meas }}$ is the concentration of nitrogen oxides measured during the tests at ppmv, and $[\mathrm{O} 2]_{\text {meas }}$ is the oxygen measured concentration during the tests.

$$
C O_{15 \%}=\frac{\left(0,21-\left[\mathrm{O}_{2}\right]_{\text {corr }}\right)}{\left(0,21-\left[\mathrm{O}_{2}\right]_{\text {meas }}\right)} * C O_{\text {meas }}
$$

where,

$\mathrm{CO}_{15 \%}$ is the concentration of carbon monoxide at $15 \% \mathrm{O}_{2}$ ppmv, and $C O_{\text {meas }}$ is the concentration of carbon monoxide measured during the tests.

These corrected values were then converted to $\mathrm{mg} / \mathrm{m}^{3}$, which is a typical unit for ambient air monitoring, with Eq. (14):

$$
C_{m g / m^{3}}=\frac{12,187 * C_{p p m v 15 \% O_{2}} * M}{(273,15+T)}
$$

Where;

$C_{m g / m}{ }^{3}$ is the concentration of gaseous pollutant at $\mathrm{mg} / \mathrm{m}^{3}, C_{\text {ppmv15\% O2 }}$ is the concentration of gaseous pollutant in ppmv at $15 \% \mathrm{O}_{2}$ (from Eq. (12) and Eq. (13)), $M$ is the molecular weight of gaseous pollutant at $\mathrm{g} / \mathrm{mole}$, and $T$ is the conversion temperature.

The AFR plays an important role in the efficiency of the combustion process. The ideal $A F R$ is referred as stoichiometric, and is the target that the feedback fuel control system constantly shoots for. If $A F R$ is less than the stoichiometric value, complete combustion cannot occur; and if $A F R$ is greater than stoichiometric value, a complete combustion can be obtained.

When testing an energy production system in the field, the measurement of the combustion air is always difficult because it is not ducted. Therefore, a methodology had to be used to measure the air fuel ratio (AFR) from emission measurements.

In this paper, the $A F R$ value can be found from the composition of a NG and the exhaust gas emissions. The composition of $\mathrm{NG}$ was obtained from the gas utility data, while the combustion TESTO gas analyzer was used to analyze a gas sample in dry base. The remaining gases are then expressed as a percentage (by volume) of the total dry gas constituents. With the Emission Performance, 
showed in Table 4, and using the Eq. (15) the combustion equation can be balanced.

$$
\begin{aligned}
& R_{1} * \mathrm{C}_{n} \mathrm{H}_{m}+R_{2} * \mathrm{~N}_{2}+\mathrm{R}_{3} * \mathrm{CO}_{2}+\mathrm{R}_{4} * \mathrm{O}_{2}+R_{5} * \mathrm{~N}_{2} \longrightarrow \\
& P_{1} * \mathrm{O}_{2}+P_{2} * \mathrm{CO}+\mathrm{P}_{3} * \mathrm{CO}_{2}+P_{4} * \mathrm{NO}+\mathrm{P}_{5} * \mathrm{NO}_{2} \ldots \\
+ & P_{6} * \mathrm{H}_{2}+P_{7} * \mathrm{HC}+P_{8} * \mathrm{H}_{2} \mathrm{O}+P_{9} * \mathrm{~N}_{2}
\end{aligned}
$$

Then the AFR value for the combustion process can be calculated, using the Eq. (16).

$$
A F R=\frac{\left(R_{4} * M_{O_{2}}+R_{5} * M_{N_{2}}\right)}{\left(R_{1} * M_{C_{n} H_{m}}+R_{2} * M_{N_{2}}+R_{3} * M_{C_{2}}\right)}
$$

Table 5 shows some parameter of NG in the emission test day.

Table 5. Measured parameters of NG in the emission test day.

\begin{tabular}{|l|c|}
\hline \multicolumn{1}{|c|}{ Parameter } & Value \\
\hline Power $_{\mathrm{MTG}}(\mathrm{kW})$ & 23,1 \\
\hline $\mathrm{T}_{\mathrm{NG}}\left({ }^{\circ} \mathrm{C}\right)$ & 29,9 \\
\hline $\mathrm{V}_{\mathrm{NG}}(\mathrm{Nm} 3 / \mathrm{h})$ & 10,89 \\
\hline $\mathrm{P}_{\mathrm{NG}}(\mathrm{kPa})$ & 92,38 \\
\hline
\end{tabular}

\section{RESULTS}

In this chapter, the performance monitoring, uncertainty analysis and emission monitoring of the gas microturbine cogeneration system, during the development of both stable and long test periods, are shown.

\section{Performance Monitoring}

In this section, the results for performance and uncertainty analyses, of the measurement parameters of microturbine cogeneration system, are presented.

Electrical and thermal performance analysis

Table 6 summarizes the average variation of operational parameters during the stable test. It can be seen that the variation during the tests is smaller than the maximum allowable one. Table 7 , and Table 8 summarizes the average performance values and the NG, water, and exhaust gases condition during the stable test period at the PUC-Rio gymnasium.

Figure 4 shows graphically the variation of frequency and voltage output during the stable test period.

Table 9 shows the performance of the microturbine CHP system during a long test period. The system was operating during peak hours, at different loads. A maximum heat recovery rate was reached when the system operated at maximum load.

When the system operates at maximum load (100 $\%$ ), it supplies $25,0 \mathrm{~kW}$ of electrical power, and 43,9 $\mathrm{kW}$ of thermal energy; while the electrical, thermal and total efficiency are $22,7 \%, 39,9 \%$, and $62,6 \%$, respectively, for a hot water flow rate of $10,7 \mathrm{~m}^{3} / \mathrm{h}$.
Table 6. Average variation for operational parameters during the stable test period.

\begin{tabular}{|c|c|c|c|c|}
\hline$\%$ & $\begin{array}{c}\mathrm{P}_{\mathrm{O}} \\
\pm 2 \%\end{array}$ & $\begin{array}{c}\mathrm{V}_{\mathrm{NG}} \\
\pm 2 \%\end{array}$ & $\begin{array}{c}\mathrm{P}_{\mathrm{AMB}} \\
\pm 2 \%\end{array}$ & $\begin{array}{c}\mathrm{T}_{\mathrm{AMB}} \\
\pm 2 \%\end{array}$ \\
\hline $100 \%$ & 0,07 & 0,57 & 0,04 & 0,12 \\
\hline $75 \%$ & 0,15 & 0,15 & 0,04 & 0,49 \\
\hline $50 \%$ & 0,92 & 0,24 & 0,05 & 0,80 \\
\hline $25 \%$ & 1,24 & 0,64 & 0,04 & 0,60 \\
\hline
\end{tabular}

Table 7. Average performance values during the stable test period.

\begin{tabular}{|c|c|c|c|c|}
\hline & $100 \%$ & $75 \%$ & $50 \%$ & $25 \%$ \\
\hline $\mathrm{T}_{\mathrm{AR}}\left({ }^{\circ} \mathrm{C}\right)$ & 29,4 & 29,0 & 28,6 & 28,5 \\
\hline $\mathrm{P}_{\mathrm{AMB}}(\mathrm{kPa})$ & 99,7 & 99,7 & 99,8 & 99,7 \\
\hline $\mathrm{HI}(\mathrm{kW})$ & 110,1 & 93,0 & 74,1 & 57,4 \\
\hline $\mathrm{P}_{\mathrm{O}}(\mathrm{kW})$ & 25,0 & 21,0 & 13,8 & 7,0 \\
\hline$\eta(\%)$ & 22,7 & 22,5 & 18,6 & 12,2 \\
\hline $\mathrm{Q}_{\mathrm{H} 2 \mathrm{O}}(\mathrm{kW})$ & 43,9 & 38,7 & 29,2 & 21,9 \\
\hline$\eta_{\mathrm{T}}(\%)$ & 39,9 & 41,6 & 39,4 & 38,1 \\
\hline$\eta_{\text {TOTAL }}(\%)$ & 62,6 & 64,2 & 58,0 & 50,3 \\
\hline
\end{tabular}

Table 8. Natural gas, water, and exhaust gas condition during the stable test period of cogeneration system.

\begin{tabular}{|l|c|c|c|c|}
\hline & $100 \%$ & $75 \%$ & $50 \%$ & $25 \%$ \\
\hline $\mathrm{V}_{\mathrm{NG}}\left(\mathrm{Nm}^{3} / \mathrm{h}\right)$ & 11,4 & 9,6 & 7,7 & 6,0 \\
\hline $\mathrm{P}_{\mathrm{NG}}(\mathrm{kPa})$ & 86,6 & 88,3 & 89,0 & 95,4 \\
\hline $\mathrm{T}_{\mathrm{NG}}\left({ }^{\circ} \mathrm{C}\right)$ & 21,2 & 21,2 & 21,0 & 21,0 \\
\hline $\mathrm{V}_{\mathrm{H} 2 \mathrm{O}}\left(\mathrm{m}^{3} / \mathrm{h}\right)$ & 10,7 & 10,7 & 10,5 & 10,7 \\
\hline$\Delta \mathrm{T}_{\mathrm{H} 2 \mathrm{O}}\left({ }^{\circ} \mathrm{C}\right)$ & 3,6 & 3,2 & 2,5 & 1,8 \\
\hline $\mathrm{T}_{\mathrm{EX} \mathrm{IN}}\left({ }^{\circ} \mathrm{C}\right)$ & 298,6 & 283,3 & 260,4 & 240,7 \\
\hline $\mathrm{T}_{\mathrm{EX} \mathrm{OUT}}\left({ }^{\circ} \mathrm{C}\right)$ & 142,0 & 130,2 & 115,3 & 100,5 \\
\hline
\end{tabular}

When the system operates at minimum load $(25$ $\%$ ), it supplies 7,0 $\mathrm{kW}$ of electrical power, and 21,9 $\mathrm{kW}$ of thermal energy; while the electrical, thermal, and total efficiency are $12,2 \%, 38,1 \%$, and 50,3 \%, respectively, for a hot water flow rate of $10,7 \mathrm{~m}^{3} / \mathrm{h}$.

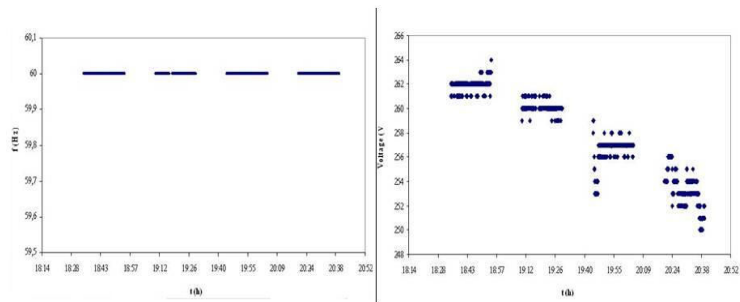

Figure 4. Frequency and Voltage Output variation during the stable test periods, cogeneration. 
Table 9. Performance average values of microturbine cogeneration system during the long test period.

\begin{tabular}{|l|c|c|c|c|c|}
\hline \multicolumn{2}{|c|}{ Condition } & \multicolumn{4}{c|}{ Tests } \\
\hline \multicolumn{1}{|c|}{ Param. } & Unit & $100 \%$ & $75 \%$ & $50 \%$ & $25 \%$ \\
\hline $\mathrm{T}_{\mathrm{AIR}}$ & ${ }^{\circ} \mathrm{C}$ & 26,6 & 27,5 & 26,8 & 28,2 \\
\hline $\mathrm{P}_{\mathrm{AMB}}$ & $\mathrm{kPa}$ & 100,3 & 100,3 & 100,0 & 100,0 \\
\hline $\mathrm{P}_{\mathrm{O}}$ & $\mathrm{kW}$ & 25,8 & 21,0 & 14,0 & 7,0 \\
\hline$\eta$ & $\%$ & 23,2 & 22,7 & 19,0 & 12,3 \\
\hline $\mathrm{T}_{\mathrm{NG}}$ & ${ }^{\circ} \mathrm{C}$ & 19,5 & 21,2 & 19,8 & 21,1 \\
\hline $\mathrm{P}_{\mathrm{NG}}$ & $\mathrm{kPa}$ & 86,4 & 87,1 & 88,3 & 91,4 \\
\hline $\mathrm{V}_{\mathrm{NG}}$ & $\mathrm{Nm}^{3} / \mathrm{h}$ & 11,6 & 9,6 & 7,7 & 5,9 \\
\hline$\Delta \mathrm{T}_{\mathrm{EX} \mathrm{GAS}}$ & ${ }^{\circ} \mathrm{C}$ & 140,9 & 129,3 & 145,9 & 152,5 \\
\hline$\Delta \mathrm{T}_{\mathrm{H} 2 \mathrm{O}}$ & ${ }^{\circ} \mathrm{C}$ & 3,2 & 2,6 & 2,4 & 1,9 \\
\hline $\mathrm{Q}_{\mathrm{H} 2 \mathrm{O}}$ & $\mathrm{kW}$ & 38,9 & 31,2 & 29,6 & 23,6 \\
\hline $\mathrm{HI}$ & $\mathrm{kW}$ & 111,3 & 92,5 & 73,7 & 57,1 \\
\hline$\eta_{\mathrm{T}}$ & $\%$ & 34,9 & 33,7 & 40,3 & 41,3 \\
\hline$\eta_{\mathrm{TOTAL}}$ & $\%$ & 58,0 & 56,4 & 59,2 & 53,6 \\
\hline
\end{tabular}

Uncertainty analysis

Table 10 shows the maximum, minimum, average and standard deviation of electrical frequency and voltage output for each phase.

Table 11 summarizes the instrument uncertainty, and uncertainty values of the parameters for nominal power output of $28 \mathrm{~kW}$, during the stable test period. The instrumentation used to measure of voltage output, current, frequency and power output was supplied by microturbine manufacturer; and the uncertainties are referenced in (Capstone, 2004).

The electric power industry accepts that the voltage output can vary to within $\pm 10 \%$ of the standard voltage $(254 \mathrm{~V})$ without causing significant disturbances to the operation of most end use equipment, and for the frequency to within $\pm 1 \%$ on the standard frequency $(60 \mathrm{~Hz})$ without causing overheating on the equipment (EPA, 2002 and EPA, 2003); Table 10, shows that the voltage output and frequency are varying within the indicated limits, for $100 \%$ of load.

The power output uncertainty is $\pm 1,7 \mathrm{~kW}$, which is greater than the recommended values in EPA (2002), and EPA (2003); this is possibly due to the high microturbine internal sensor uncertainty of $\pm 1,0$ $\mathrm{kW}$. The same thing happened to voltage and current output; current output meter uncertainty was $\pm 1,1 \mathrm{~A}$ and voltage output meter uncertainty was $\pm 6,9 \mathrm{~V}$.

The NG LHV uncertainty, as shown in Table 11, is $\pm 680 \mathrm{~kJ} / \mathrm{Nm}^{3}$. As shown in Mendes and Rosário (1995), it influences all LHV depend parameters like, electrical efficiency uncertainty $( \pm 4,2 \%)$, thermal efficiency uncertainty ( $\pm 9,1 \%$ ), water heat recovered $( \pm 6,8 \mathrm{~kW})$ and energy input uncertainty $( \pm$ $18,7 \mathrm{~kW})$.
Table 10. Maximum, minimum, average and standard deviation of frequency and voltage output.

\begin{tabular}{|c|l|c|c|c|c|}
\hline$\%$ & Value & $\begin{array}{c}\mathrm{f} \\
(\mathrm{Hz})\end{array}$ & $\begin{array}{c}\mathrm{V}_{\mathrm{A}} \\
(\mathrm{V})\end{array}$ & $\begin{array}{c}\mathrm{V}_{\mathrm{B}} \\
(\mathrm{V})\end{array}$ & $\begin{array}{c}\mathrm{V}_{\mathrm{C}} \\
(\mathrm{V})\end{array}$ \\
\hline \multirow{4}{*}{$100 \%$} & Avg. & 60,0 & 262 & 261 & 263 \\
\cline { 2 - 6 } & Max. & 60,0 & 263 & 262 & 264 \\
\cline { 2 - 6 } & Min. & 60,0 & 262 & 260 & 262 \\
\cline { 2 - 6 } & St. Dev. & 0,0 & 0,5 & 0,9 & 0,9 \\
\hline \multirow{4}{*}{$75 \%$} & Avg. & 60,0 & 260 & 258 & 261 \\
\cline { 2 - 6 } & Max. & 60,0 & 260 & 259 & 261 \\
\cline { 2 - 6 } & Min. & 60,0 & 260 & 258 & 261 \\
\cline { 2 - 6 } & St. Dev. & 0,0 & 0,0 & 0,6 & 0,0 \\
\hline \multirow{4}{*}{$50 \%$} & Avg. & 60,0 & 257 & 255 & 258 \\
\cline { 2 - 6 } & Max. & 60,0 & 257 & 255 & 259 \\
\cline { 2 - 6 } & Min. & 60,0 & 257 & 254 & 258 \\
\cline { 2 - 6 } & St. Dev. & 0,0 & 0,0 & 0,5 & 0,5 \\
\hline \multirow{3}{*}{$25 \%$} & Avg. & 60,0 & 253 & 250 & 254 \\
\cline { 2 - 6 } & Max. & 60,0 & 254 & 251 & 255 \\
\cline { 2 - 6 } & Min. & 60,0 & 251 & 248 & 252 \\
\cline { 2 - 6 } & St. Dev. & 0,0 & 1,4 & 1,5 & 1,3 \\
\hline
\end{tabular}

Table 11. Uncertainty values during the stable test period.

\begin{tabular}{|c|c|c|}
\hline Parameter & $\begin{array}{l}\text { Instrument } \\
\text { uncertainty }\end{array}$ & $\begin{array}{c}\text { Measurement } \\
\text { uncertainty }\end{array}$ \\
\hline $\mathrm{V}_{\mathrm{A}}, \mathrm{V}_{\mathrm{B}}, \mathrm{V}_{\mathrm{C}}(\mathrm{V})$ & $\pm 6,9$ & \pm 12 \\
\hline $\mathrm{I}_{\mathrm{A}}(\mathrm{A})$ & \multirow{2}{*}{ $\pm 1,1$} & $\pm 2,5$ \\
\hline $\mathrm{I}_{\mathrm{B}}, \mathrm{I}_{\mathrm{C}}(\mathrm{A})$ & & $\pm 1,8$ \\
\hline $\mathrm{f}(\mathrm{Hz})$ & $\pm 0,03$ & $\pm 0,05$ \\
\hline $\mathrm{P}_{\mathrm{O}}(\mathrm{kW})$ & $\pm 1,0$ & $\pm 1,7$ \\
\hline$\eta(\%)$ & \multirow{2}{*}{--} & $\pm 4,2$ \\
\hline $\mathrm{HI}(\mathrm{kW})$ & & \pm 19 \\
\hline $\mathrm{V}_{\mathrm{NG}}\left(\mathrm{m}^{3} / \mathrm{h}\right)$ & $\pm 0,36$ & $\pm 0,62$ \\
\hline $\mathrm{P}_{\mathrm{NG}}(\mathrm{kPa})$ & $\pm 6,5$ & \pm 11 \\
\hline $\mathrm{T}\left({ }^{\circ} \mathrm{C}\right)$ & $\pm 0,6$ & $\pm 1,0$ \\
\hline $\operatorname{LHV}_{\mathrm{NG}}\left(\mathrm{kJ} / \mathrm{Nm}^{3}\right)$ & \multirow{2}{*}{--} & \pm 680 \\
\hline$\eta_{\mathrm{T}}(\%)$ & & $\pm 9,1$ \\
\hline $\mathrm{V}_{\mathrm{H} 2 \mathrm{O}}\left(\mathrm{m}^{3} / \mathrm{h}\right)$ & $\pm 0,18$ & $\pm 0,3$ \\
\hline $\mathrm{Q}_{\mathrm{H} 2 \mathrm{O}}(\mathrm{kW})$ & -- & $\pm 6,8$ \\
\hline
\end{tabular}

\section{Emission Monitoring}

The emission study of the CHP test system was performed over a wide range of microturbine nominal power output $(28,21,14$ and $7 \mathrm{~kW})$. Figure 5 and Figure 6, respectively, present the measured values of $\mathrm{CO}$ and $\mathrm{NO}_{\mathrm{x}}$ emissions, in ppmv at $15 \% \mathrm{O}_{2}$, as a function of the nominal power output. These results show the significant influence of the nominal power output on emission rate. The minimum cumulative rate of $\mathrm{CO}$ and $\mathrm{NO}_{\mathrm{x}}$ is observed at full nominal power output $(28 \mathrm{~kW}): 2,80 \mathrm{ppmv}$ at $15 \% \mathrm{O}_{2}\left(3,12 \mathrm{mg} / \mathrm{m}^{3}\right)$ of $\mathrm{CO}$, and $1,48 \mathrm{ppmv}$ at $15 \% \mathrm{O}_{2}\left(2,72 \mathrm{mg} / \mathrm{m}^{3}\right)$ of $\mathrm{NO}_{\mathrm{x}}$. These data are within the limits specified by the manufacturer $\left(40\right.$ ppmv at $15 \% \mathrm{O}_{2}$ of $\mathrm{CO}$ and 9 ppmv at $15 \% \mathrm{O}_{2}$ of $\mathrm{NO}_{\mathrm{x}}$ ), which are shown in Table 12 (De Carvalho and Teixeira, 2003).

Such as shown in Fig. 5 and 6, when decreasing the microturbine nominal power output, the emission 
rate of $\mathrm{CO}$ and $\mathrm{NO}_{\mathrm{x}}$, increases; the maximum $\mathrm{CO}$ and $\mathrm{NO}_{\mathrm{x}}$ levels were observed at the nominal power output of 7 and $14 \mathrm{~kW}$, respectively. Figure 6, shows that the cumulative $\mathrm{CO}+\mathrm{NO}_{\mathrm{x}}$ emission rate increases gradually with reduction of the microturbine nominal power output.

Table 12. Comparison between measured and manufacturer values of emissions from microturbine (ppm@15\% $\mathrm{O}_{2}$ ).

\begin{tabular}{|l|c|c|}
\hline $\begin{array}{c}\text { Emission } \\
\text { Gas }\end{array}$ & $\begin{array}{c}\text { Calculated } \\
\text { value }\end{array}$ & $\begin{array}{c}\text { Manufacturer } \\
\text { value }\end{array}$ \\
\hline $\mathrm{CO}$ & 2,80 & 40 \\
\hline $\mathrm{NO}_{\mathrm{X}}$ & 1,48 & 9 \\
\hline
\end{tabular}

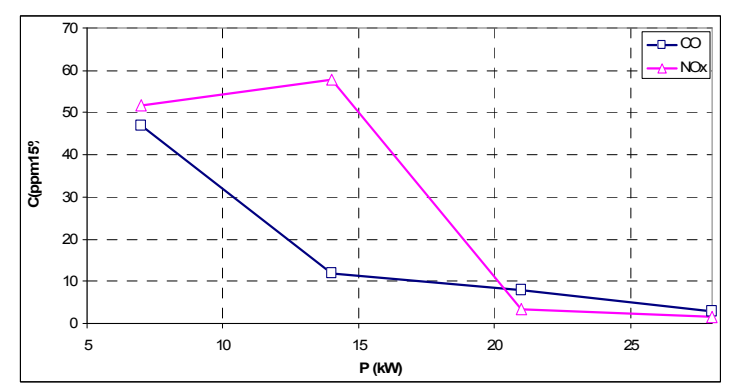

Figure 5. Concentration of CO and NOx (ppmv at $15 \% \mathrm{O}_{2}$ ) vs microturbine nominal power output

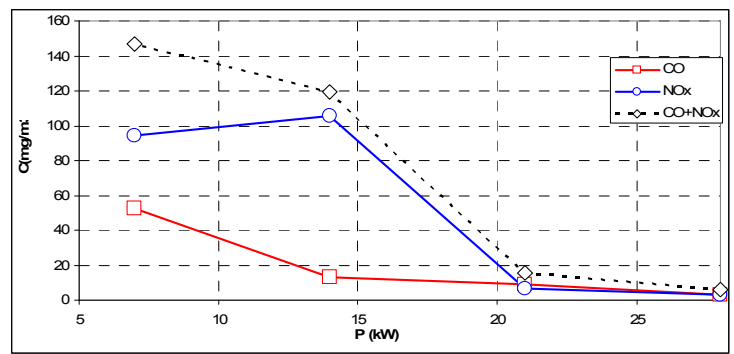

Figure 6. Concentration of $\mathrm{CO}$ and $\mathrm{NOx}\left(\mathrm{mg} / \mathrm{m}^{3}\right) \mathrm{vs}$ microturbine nominal power output.

Figure 7 shows the variation of oxygen, and carbon dioxide concentrations with the microturbine nominal power output. $\mathrm{O}_{2}$ concentration, in flue gas emission, increases with the microturbine nominal power output reduction, while $\mathrm{CO}_{2}$ concentration decreases with it.

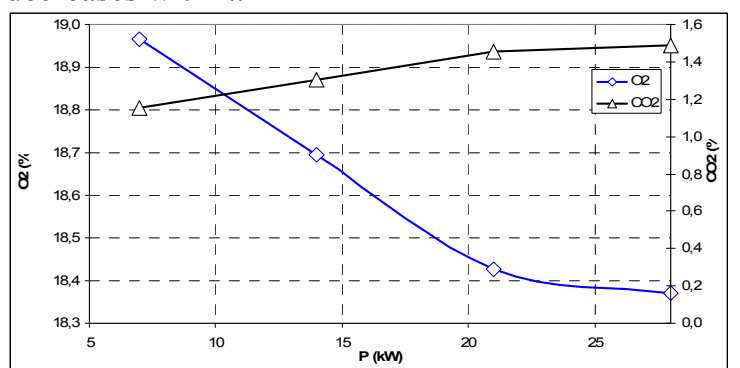

Figure 7. Concentration of $\mathrm{O}_{2}$ and $\mathrm{CO}_{2}$ vs microturbine nominal power output.

Then, the balance of combustion equation (Eq. (15)), and the $A F R$ (Eq. (16)), resulting in:
$0,01435 * C_{103,57} H_{405,15}+0,01 * \mathrm{~N}_{2}+0,0042 * \mathrm{CO}_{2}+$ $21,309 * \mathrm{O}_{2}+79,441 * \mathrm{~N}_{2} \rightarrow 18,37 * \mathrm{O}_{2}+0,0001 * \mathrm{CO}+$ $1,49 * \mathrm{CO}_{2}+0,000065 * \mathrm{NO}+0,0006 * \mathrm{H}_{2}+$ $0,0008 * \mathrm{HC}+2,906 * \mathrm{H}_{2} \mathrm{O}+80,138 * \mathrm{~N}_{2}$

$$
A F R=121
$$

\section{POTENTIAL MARKET DISPLACEMENT}

The potential market displacement from the utility company by the microturbine in the city of Rio de Janeiro, Brazil, was estimated using the available data bank for 7980 clients, including residential, commercial, industrial and government type electric energy supply contracts, during peak periods $(17: 30$ to 20:30, except weekends), and off peak periods.

The internal rate of return of the investment in the gas fired microturbine was calculate considering an investment cost of US\$ $1200 / \mathrm{kW}, \mathrm{O} \& \mathrm{M}$ cost of US\$ $15 / \mathrm{MWh}$, and an analysis period of 15 years. Utility energy tariffs for both electricity and natural gas included type of contract and period of the day, for both power and energy consumption.

The criteria for selecting the clients that would potentially migrate from electric energy supply by the utility company to gas fire microturbine electric energy production was an internal rate of return of investment of at least $15 \%$ a year.

As a first result, residential type clients (same tariff for both peak and off peak periods) were excluded from the list of potential clients. It was also concluded the potential clients would have only to operate the microturbine during peak periods, so that its operation would be economically feasible. Thus, 835 clients were selected out of 7980 .

The electric energy potential market displacement from the utility company was then calculated in $473 \mathrm{MW}$ and $33703 \mathrm{MWh} / \mathrm{month}$, which is small when compared to the amount of commercialized energy by the utility company.

Therefore, it was concluded that the use of a microturbine to produce electric energy is not presently a matter of concern to the utility company.

\section{CONCLUSIONS}

On time tests confirmed the manufacturer's specifications. Field measurements are not generally considered to be as accurate as the laboratory measurements upon which the manufacturer's ratings are presumably based. Electrical capacity was measured; it demonstrated that the system can be maintained in continuous synchronization with the utility grid, within the usually accepted values by industry.

An uncertainty analysis shows that if smaller uncertainty values are required to meet the commissioning values, the $L H V$ must be measured during the test, and not as a daily average, as supplied by the utility company. 
Emissions tests of the microturbine based CHP system have been conducted to determine the emissions output for a variable nominal power output. Operation at reduced microturbine nominal power levels increases the cumulative emissions (CO $+\mathrm{NO}_{\mathrm{x}}$ ) of the flue gas components. Results of tests showed that the operation of the microturbine at full load power output produces the lowest emissions of air pollutants (primarily $\mathrm{CO}$ and $\mathrm{NO}_{\mathrm{x}}$ ). The latter are within limits specified by the microturbine manufacturer.

A methodology was used to measure the $A F R$, without ducting the combustion air, what is always difficult in the field.

Finally, the cogeneration potential of the microturbine based system was evaluated. The results show that the overall usage of the fuel chemical energy was not very high. The choice of the operating conditions of the waste heat boiler must be done in order to optimize the system efficiency.

The electric energy potential market displacement from the utility company by the gas fired microturbine was estimated, showing that it should not be a matter of concern to the present supplier of electricity to the client, which would migrate to a gas supplier.

\section{ACKNOWLEDGEMENTS}

The authors would like to express their acknowledgment to LIGHT (local utility company of Rio de Janeiro - Brazil), for the financial support provided for the present study.

\section{REFERENCES}

ASHRAE, Air Conditioning Systems Design Manual, Chapter 7, 2001, Ed. American Society of Heating, Refrigerating and Air-Conditioning Engineers.

ASME PTC-22, 1997, Performance Test Code for Gas Turbines, The American Society of Mechanical Engineers, United States.

Assunção, A. S. and Orlando, A. F., 2004, A procedure for commissioning a microturbine electric energy generating power plant, in: Brazilian Congress of Thermal Sciences and Engineering ENCIT 2004, Rio de Janeiro - Brazil.

Capstone Turbine Corporation, March 2001, System Operation, 511715-002.

Capstone Turbine Corporation, Rev. C, 2004, Technical Reference Grid Connect Operation Capstone Model C30 and C60, 410027-001.

Capstone Turbine Corporation, 2000, Capstone low emissions microturbine technology.

De Carvalho Júnior J. A, Teixeira, P. L., 2003, Emissões em processos de combustão, Ed. UNESP.

EPA (U.S. Environmental Protection Agency), 2003, Combined Heat and Power at a Commercial
Supermarket - Capstone $60 \mathrm{~kW}$ Microturbine CHP System.

EPA (U.S. Environmental Protection Agency), 2002, Greenhouse Gas (GHG) Verification Guidelines Series - Natural Gas-Fired Microturbine Electrical Generators.

EPA (U.S. Environmental Protection Agency), 2002, Climate Protection Partnership Division, Technology characterization: microturbines.

EPA (U.S. Environmental Protection Agency), 2003, Environmental Technology Verification Report, TESTO Inc. model 350 portable multigas emission analyzer.

EPA (U.S. Environmental Protection Agency), 1993, Office of Air and Radiation, Alternative control techniques document $-\mathrm{NO}_{\mathrm{x}}$ emissions from stationary gas turbine.

Herschy, R. W., 2002, The uncertainty in a current meter measurement, Flow Measurement and Instrumentation, pp. 281-284.

Ho, J. C., Chua, K. J. and Chou, S. K., 2004, Performance study of a microturbine system for cogeneration application, Renewable Energy, pp. 1121-1133.

Huamaní, M. M., 2005, Geração de Perfis Elétrico e Térmico para Otimização de um Sistema de Cogeração, Master Dissertation of PUC-Rio.

ISO GUM, 1995, Guia para a expressão da Incerteza de Medição, INMETRO.

Mendes, A. and Rosário, P. P., 1995, Metrologia \& Incerteza de Medição, INMETRO.

Onovwiona, H. I. and Ugursal, V. I., 2006, Residential cogeneration systems: review of the current technology, Renewable \& Sustainable Energy Reviews, pp. 389-431.

Orlando, J. A., 1996, Cogeneration Design Guide, Ed. American Society of Heating, Refrigerating and Air-Conditioning Engineers, Inc., Georgia, United States,

Kehlhofer, R., Bachmann, R., Nielsen, H. and Warner, J., 1999, Combined - Cycle Gas Steam Turbine Power Plants, PennWell Publishing Company, Second Edition. 